\title{
【特＼cjkstart集： 容器包装プラスチックのリサイクルと今後】
}

\section{小売業界からみた容器包装プラスチックの $3 \mathrm{R}$}

\author{
上山靜 一 *
}

【要旨】容器包装リサイクル法が対象としているプラスチックのリサイクルについては, 未だ多くの 課題が顕在化し議論されている。本稿では消費者に最も近い位置の産業である小売業界の視点でこれま での取り組みと最新状況，ならびに今後のあり方についてとりあげる。

容器包装の三大機能は内容物の保護, マーケティング機能としての情報提供, そして取り扱いの利便 性であるが，その一方で単一素材化などの環境配慮の必要性も指摘されている。これらのバランスをど うとっていくのかという課題とともにリデュース施策の重要性も増加してきている。小売業界は 40 年 程前から幾多の施策でこの問題に取り組んで来たが, 常に地域の消費者, 行政との連携を軸に展開し, 社会の持続可能性を追求してきた。

現在の容器包装リサイクル法の課題は透明性, 公平性の確保である。加えて再生プラスチックやバイ オマスなどの植物由来プラスチックの普及を目指す企業に対するインセンティブ設計の必要性や, 消費 者への「環境配慮商品の選択への誘導策」の必要性に対する具体的制度設計の議論が今こそ求められて いる。

キーワード：DfE (環境配慮設計)，連携，リデュース，グリーン購入，透明性・公平性

\section{1. は じめ に}

日本の容器包装リサイクル法の制度設計に一つの影響 を与えたとされる OECD の EPR (Extended Producer Responsibility）のガイダンスマニュアルは, 消費者が 環境を意識して商品を選択すべき重要な役割を担ってい るにも関わらず，その役割を果たしていないと指摘して いる。そして情報提供と消費者教育が重要であることを 強調している。しかし OECD も認めているように, 消 費者の購買行動は商品の価格対価值を第一としていると みられ, 環境配慮商品の選択に誘導することは容易では ない1)。

しかし, 次世代に対する現世代の責任として, 循環型 社会, あるいは低炭素社会の構築に向けたこれらの努力 は容易でなくても継続しなければならない。努力の方向

原稿受付 2010.7.20

*流通環境経営研究所

(元イオンリテール(侏) 常務取締役 環境・社会貢献担当)

連絡先：テ 362-0042 埼玉県上尾市谷津 2-5-23-101
として, 消費者, 行政, 事業者等の各セクターが情報共 有や共同行動で連携し, 経済成長（生産性向上）と環境 負荷低減が両立する環境配慮商品の選択などの具体的モ デルづくりに成功することがあげられる。そのとき小売 業は消費者に最も近い位置にある産業として貢献が期待 されている。

廃棄物問題のモデルづくりで最も配慮しなければなら ないことの一つが「地域性」である。小売業は地域産業 でもあり，一つひとつの店舗はその「地域性」の具体化 (品揃えや店舗運営など) が成否のカギといっても過言で はない。小売店舗が地域住民（消費者）や地域行政と連 携し当該地域の問題解決を前進させた成功事例（ベスト プラクティス) づくりが求められる。容器包装プラス チックは, 容器包装リサイクル法対象物の中で, 最も構成 比の高いものであり, その 3R（Reduce Reuse Recycle） の前進が社会に与える影響は大きいものがある。

私たちは, この容器包装プラスチックの $3 \mathrm{R} の$ 前進の 成功事例を具体的につくり, 他へ広げることから始める べきである。 


\section{2. 容器包装プラスチックに求める機能}

\section{1 容器包装プラスチックの三大機能}

\section{1 .1 三大機能と環境配慮}

容器包装は内容物の保護機能が第一に求められている。 食品での衛生管理上の配慮など, それは最優先の機能で ある。次にマーケティグ機能としての消費者への適正な 情報提供があげられる。そして 3 番目は取り扱いの利便 性の機能である。

この, 内容物の保護, 適正な情報提供, そして取り扱 いの利便性は, 容器包装の三大機能であり重視しなけれ ばならない。一方, 環境配慮についてはリデュースの推 進が第一と思われる。レジ袋の無料配布の中止による大 幅削減や簡易包装の徹底, あるいは素材を非食糧系の植 物由来 (バイオマス) に切替える, 化石資源の減量化を 図るなどである。

\section{1 .2 複合素材の容器包装プラスチックと環境負荷}

2010 年 3 月 30 日に開催された中央環境審議会と産業 構造審議会のプラスチック製容器包装に係る再商品化手 法合同会合において, 財食品産業センターより「単一素 材 (単体 CPP 包材) と多層化包材の環境負荷の比較」 の発表があった。結論として, 食品容器包装の機能を十 全に発揮するためには, 単一素材では機能面で劣るだけ でなく，資源の大量消費によりかえって環境負荷を増大 させるとしている。レトルトカレーの包材の例示はわか りやすく, 多層化包材の場合, 単体 CPP 包材と比べ, 品質保持期間が長くなることや包材の減量が図られるこ とを示している。また金属との複合については，金属の 混入をできるだけ少なくするため, アルミ箔からアルミ 蒸着などへの切り替えなど工夫を行っているとしている。 これらの動向 (情報) は消費者にわかりやすく伝え, 消 費者の環境配慮商品の選択（グリーン購入）につなげて いくことが必要である(図 1) ${ }^{2)}$ 。

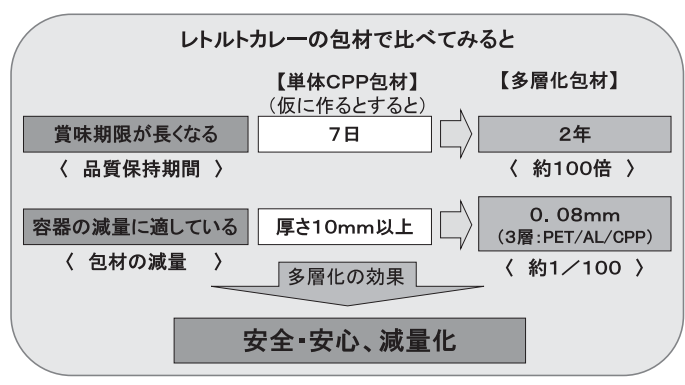

※2010年 3 月 30 日 中央環境審議会, 産業構造審議会の合同会合での (財) 食品産業センター 発表資料より抜粋

図 1 容器包装の保護機能（積層フィルム）
3. 小売業界における容器包装プラスチックの $3 R$ の取り組み

\section{1 日本チェーンストア協会の取り組み}

\section{1 .1 容器包装の店頭回収}

日本チェーンストア協会では, 統計を取り始めた 1995 年度より, 本格的にペットボトルや発泡スチロー ルトレイ等の店頭回収を推進している。現在, 実施して いる店舗は日本全国で 4,600 店舗（2008 年度末）に拡大 し, 回収年間総量はペットボトルで 13.209 ton（2008 年 度末), 発泡スチロールトレイで 12.039 ton（同）となっ ている。特に 1998 年度より 2003 年度にかけて急拡大し ていたが, その後, 6 年間は横ばい傾向となっている。 今後は, 自治体との連携を強化する等の施策で店頭回収 可能店舗を拡大することが必要である(図 2) ${ }^{3)}$ 。

3.1 .2 容器包装の適正化 (削減)

日本チェーンストア協会では, 1972 年度より「包装 適正化要綱」を作成し過㮃包装の排除に取り組んでいる。 これは, 商業包装に扔ける過剩, 過大包装を排除し, 流 通コストの低減, 廃棄物処理の負担軽減に資するととも に環境保全, 消費者の便益, 商品の保護, 品質の保全, 衛生管理および流通の合理化, 近代化に寄与する適正な 包装の推進を図ることを目的としている。「要綱」には 「包装適正化推進要綱」「青果物包装改善要綱」,「塩干物 包装改善要綱」がある(図 $3 \cdot$ 表 1$)^{4)}$ 。

\section{1 .3 レジ袋の発生抑制}

協会会員各社は, 1998 年頃から, 各地の自治体や市
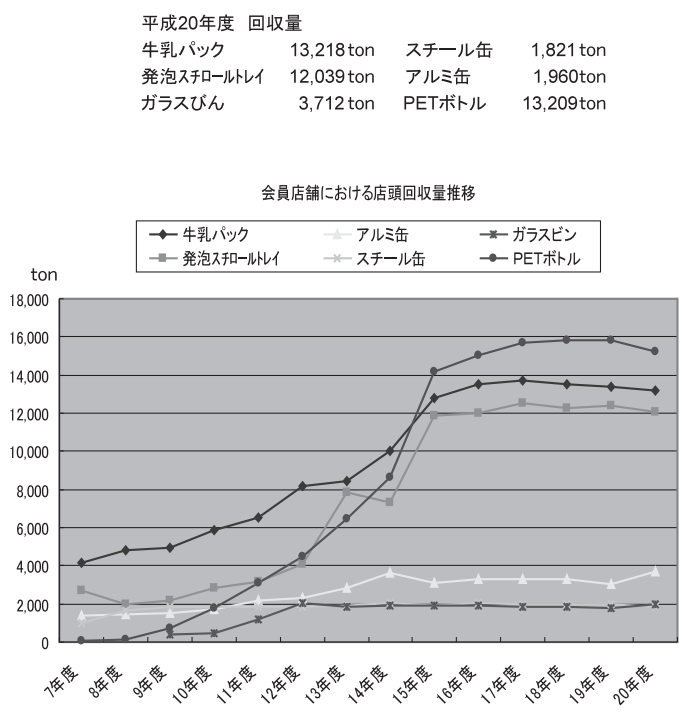

（2008 年度 日本チェーンストア協会加盟 4,600 店舗）

図 2 容器包装の店頭回収量 
日本チェーンストア協会では、

過剩包装を防ぐため 1972 (昭和 47 年)に「包装適正化要綱」を 策定し、品質保持と省資源 に努力

\begin{tabular}{|l|}
\hline @包装適正化推進要綱 \\
@青果物包装改善要綱 \\
@塩干物包装改善要綱
\end{tabular}

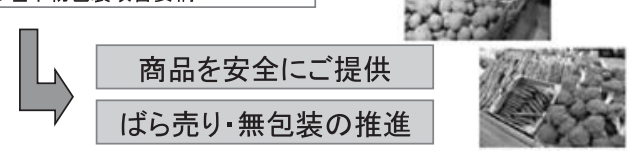

図 3 日本チェーンストア協会の包装適正化要綱

民団体等と連携しながら「マイバッグでお買物キャン ペーン」を展開し、レジ袋の発生抑制に取り組んできた。 その中で, 2007 年 3 月に新たな削減目標として「2010 年度末までに会員企業平均のレジ袋辞退率 30\%」を設 置し運動を強化している。特に2007 年 1 月から始まっ たジャスコ東山二条店でのレジ袋無料配布中止による大 幅削減以降の新しい盛り上がりにより，2010 年 1 月時 点の会員企業平均のレジ袋辞退率は $24.35 \%$ となり目標 達成の可能性がでてきている（図 4 ・表 2) 5)。また, イ オン(株)（現イオンリテール(株)）は2007 年 4 月 16 日，環 境省との間で, 循環型社会の構築に向けた取り組みに関
表 1 青果物におけるトレイ包装の具体的指標【抜粋】

\begin{tabular}{|l|c|l|c|}
\hline \multicolumn{1}{|c|}{ 品名 } & 区分 & \multicolumn{1}{|c|}{ 品名 } & 区分 \\
\hline 【根菜類】 & & 【まめ科野菜】 & \\
\hline だいこん & $\times$ & さやいんげん & $\times$ \\
\hline かぶ & $\times$ & さやえんどう & $\times$ \\
\hline にんじん & $\times$ & さやを除いた豆 & $\bigcirc$ \\
\hline ごぼう & $\times$ & もやし & $\times$ \\
\hline たけのこ & $\times$ & えだまめ & $\times$ \\
\hline くわい & $\bigcirc$ & & \\
\hline 【果菜類】 & & 【核果類】 & \\
\hline きゅうり & $\times$ & もも & $\bigcirc$ \\
\hline うり & $\times$ & すもも & $\bigcirc$ \\
\hline かぼちゃ & $\times$ & さくらんほ & $\bigcirc$ \\
\hline なす & $\bigcirc$ & & \\
\hline トマト & $\times$ & & \\
\hline ししとう & $\times$ & & \\
\hline おくら & & \\
\hline
\end{tabular}

×：トレイの使用を必要としないもの

○：保鮮・保質の必要上トレイを使用するもの

する協定を締結し，2010 年度までにマイバッグ持参率 全店平均 $50 \%$ 以上達成等を目標, そのために自主協定 制度を活用し，レジ袋無料配布を中止し大幅削減をする 店舗を全国に展開, 2010 年度までに当該店舗のマイ バッグ持参率を $80 \%$ 以上にすることを目指すとした。

\section{「2010年度末までに会員企業平均のレジ袋辞退率30\%」を新たな目標に設定 ○レジ袋辞退率の推移}
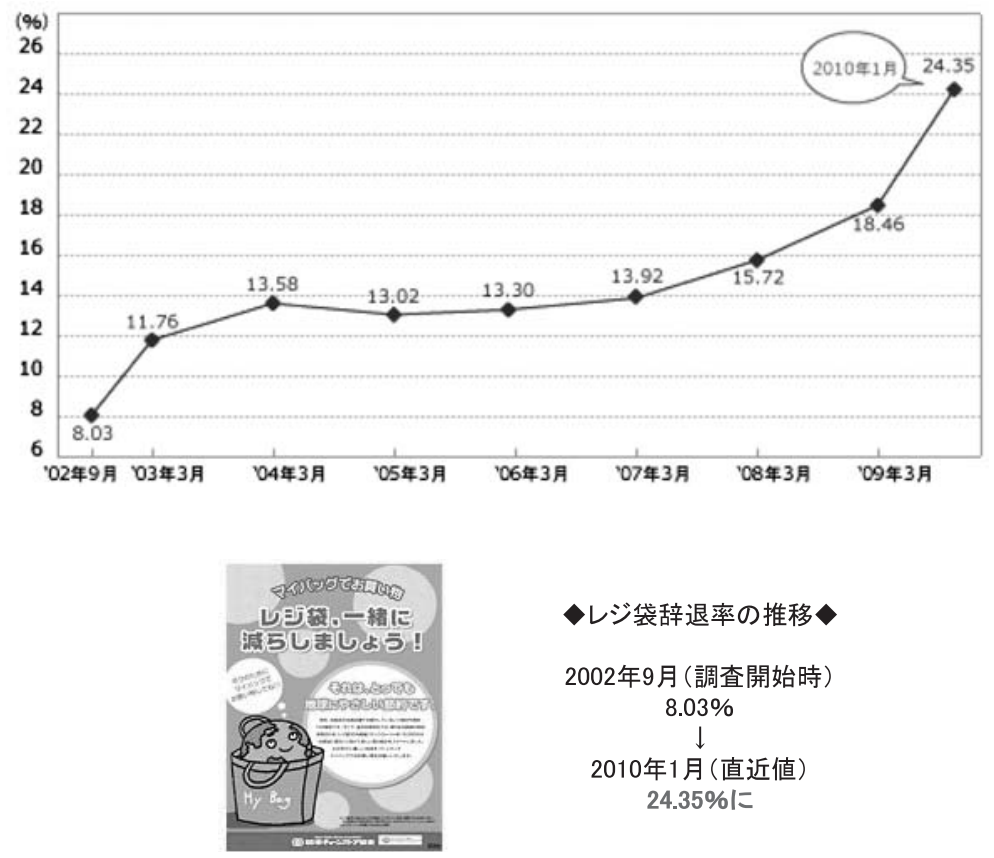

日本チェーンストア協会主要会員 58 社

図 4 レジ袋辞退率の推移 
表 2 レジ袋無料配布中止による大幅削減実施の店舗数（日本チェーンストア協会）

2010 年 1 月現在, 29 都道府県, 40 社 1369 店舗にて実施中

\begin{tabular}{|c|c|c|c|c|c|}
\hline $\begin{array}{l}\text { - 北海道 } \\
\text { - 青森県 } \\
\text { - 宮城県 } \\
\text { - 山形県 } \\
\text { • 福島県 } \\
\text { - 茨城県 } \\
\text { - 枋木県 } \\
\text { • 埼玉県 } \\
\text { • 東京都 } \\
\text { - 神奈川県 }\end{array}$ & $\begin{array}{r}145 \text { 店舗 } \\
35 \text { 店舗 } \\
43 \text { 店舗 } \\
17 \text { 店舗 } \\
41 \text { 店舗 } \\
112 \text { 店舗 } \\
1 \text { 店舗 } \\
15 \text { 店舗 } \\
13 \text { 店舗 } \\
7 \text { 店舗 }\end{array}$ & $\begin{array}{l}\text { - 富山県 } \\
\text { - 石川県 } \\
\text { - 福井県 } \\
\text { - 山梨県 } \\
\text { - 長野県 } \\
\text { - 岐阜県 } \\
\text { - 静岡県 } \\
\text { - 愛知県 } \\
\text { - 三重県 } \\
\text { - 京都府 }\end{array}$ & $\begin{array}{r}51 \text { 店舗 } \\
9 \text { 店舗 } \\
8 \text { 店舗 } \\
13 \text { 店舗 } \\
5 \text { 店舗 } \\
105 \text { 店舗 } \\
125 \text { 店舗 } \\
223 \text { 店舗 } \\
121 \text { 店舗 } \\
6 \text { 店舗 }\end{array}$ & $\begin{array}{l}\text { • 大阪府 } \\
\text { • 兵庫県 } \\
\text { • 和歌山県 } \\
\text { • 岡山県 } \\
\text { • 広島県 } \\
\text { • 山口県 } \\
\text { • 愛媛県 } \\
\text { • 高知県 } \\
\text { • 長崎県 }\end{array}$ & $\begin{array}{r}2 \text { 店舗 } \\
57 \text { 店舗 } \\
57 \text { 店舗 } \\
4 \text { 店舗 } \\
22 \text { 店舗 } \\
124 \text { 店舗 } \\
5 \text { 店舗 } \\
2 \text { 店舗 } \\
1 \text { 店舗 }\end{array}$ \\
\hline
\end{tabular}

プラスチック製容器包装使用量

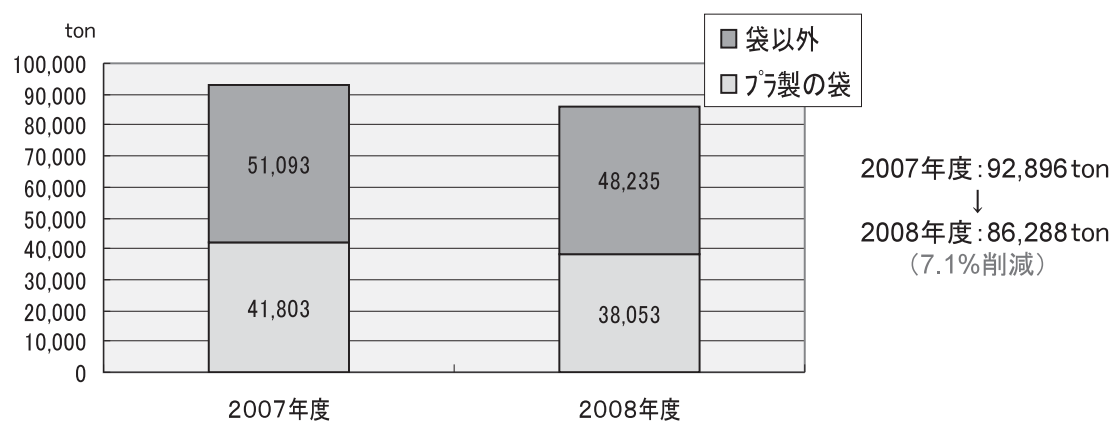

※ 日本チェーンストア協会主要会員 58 社（売上シェア $84 \%$ ) デー夕

※「プラ製の袋」は主にレジ袋およびタイミーパック $(9.0 \%$ 減 $)$

※「袋以外は」主にトレイ等の容器資材 $(5.6 \%$ 減 $)$

図 5 容器包装利用量の削減 (日本チェーンストア協会)

結果, 2010 年 2 月 28 日現在全店平均のマイバッグ持参 率は $60.4 \%$ を達成，当該店舗の同持参率は大半の店舗 で $80 \%$ を超えている。

\subsection{4 プラスチック製容器包装利用量の削減}

上記の取り組み等により，日本チェーンストア協会主 要会員 58 社（売上シェア 84\%）のプラスチック製容器 包装利用量は 2007 年度 92.896 ton から翌 2008 年度には 86.288 ton と $7.1 \%$ の削減となっている。内訳は「レジ袋 とタイミーパック（レジの後のサッカー台等にある小 袋)」で 9.0\%の削減, トレイ等の容器資材で $5.6 \%$ 削減 となっている (図 5) ${ }^{6)}$ 。

\section{2 会員企業の取り組み事例}

\section{2 .1 バイオマス PE 製レジ袋の試験販売}

日本チェーンストア協会加盟企業のイオンリテール(株) は 2010 年 2 月 22 日〜 3 月 7 日の期間, 埼玉県の同社越 谷レイクタウン店でサトウキビから砂糖を製造したあと の副産物（廃糖蜜）を原料にして作られたポリエチレン を使用（バイオマス比率 98\%）したレジ袋を 1 枚 5 円 で試験販売 (2 万枚) をした。これは, マイバッグ使用 による発生抑制を主活動としているが、レジ袋はゼロに

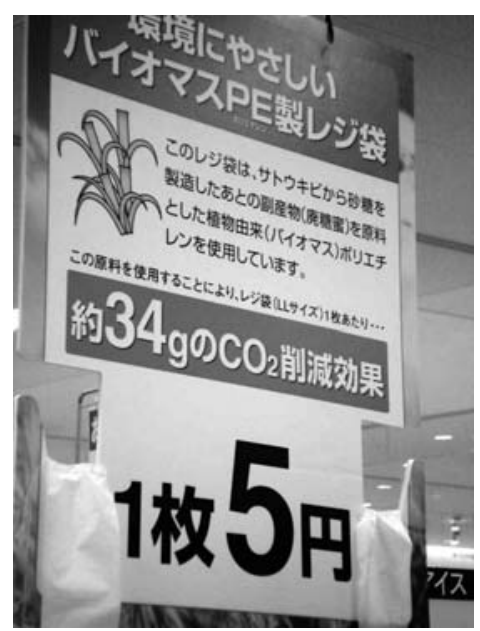

図 6 イオン越谷レイクタウン店での案内掲示物

はならないので, 一部, 通勤帰り等でレジ袋を購入され るケースでも, 化石燃料からバイオマス PEに素材変更 することにより, $\mathrm{CO}_{2}$ 削減と化石資源の節約を達成し ようとする取り組みである (図 6 参照)。 
3.2 .2 ごみ減装 (へらそう) 実験'09・'10への参画 神戸大学大学院経済学研究科の石川雅紀教授が代表を 務める「NPO 法人ごみじゃぱん」がすすめる「減装 ショッピング (簡易包装普及運動)」の’09・'10 実験は, 2009 年 11 月よりスタートしているが, その取り組みに 実験店舗として，コープこうベシーア，ダイエー甲南店， そしてジャスコつくしが丘店の 3 店舗が参加している。 この活動は 2005 年より石川教授が取り組み, 毎年進化 している。2008 年の「減装ショッピング」(3ケ月間) では, 簡易包装として推奨した商品が消費者の支持を受 け, 食品で $8.52 \%$, 生活雑貨で $14.4 \%$ キャンペーンによ る売上増加効果があったことが示された。また, 実験の 結果, 4 店舗（コープこうべ 2 店舗, ダイエー 2 店舗 $)$ で 1.18 ton の包装ごみが削減され, $\mathrm{CO}_{2}$ も 2.03 ton 削減 された。

’09・'10 実験は神戸市東灘区および北区を実験地域と し, 学生が上記 3 店舗で販売されている商品の内, 約 1,500 種類の商品について包装の重量を測定し, カテゴ リー分類し, カテゴリーごとに中身あたりの包装重量の 少ない商品を合計 384 種類推奨している（2010 年 4 月 7 日現在)。現在, さらに追加推奨を増やす予定である。こ の取り組みは, 消費者 (生活者) の意識構造 (行動) と包 装ごみの発生抑制を結びつけることができる可能性の検 証と, さらには C $\rightarrow \mathrm{B}$ (Customer $\rightarrow$ Business) のリレー ション強化, すなわち, 消費者 (生活者) の意識的働き かけにより企業行動に社会的に見て良い影響を与える ディファクトスタンダードづくりの意味を持っている7)。 3.2 .3 レジ袋の発生抑制に向けた自主協定の意味

イオングループは 2007 年 1 月よりレジ袋無料配布の 中止による大幅削減を地域の自治体および市民団体等と の自主協定締結方式で進めており，2010年 2 月 20 日現 在, 315 都市, 867 店舗で $80 \%$ を超えるレジ袋の発生抑 制を達成している。また, 自主協定締結都市は 300 を超 えている。これらの都市 (市町村) では「レジ袋の無料 配布の中止による大幅削減」をテーマに約 1 年間, 話し 合いを続けているが, レジ袋の大幅削減がほぼ達成でき た地域では，その協議の場自体が自主的に次の環境保全 の課題を設定（例：簡易包装推進, 子供達の環境教育推 進, マイハシ運動）し, 活動を展開するという進化が見 られる。その動きは地域での自主的な問題解決力の向上 という意義があると思われる。

3.2 .4 カーボンフットプリント制度の推進

経済産業省を中心とした政府各省連携のカーボンフッ トプリント制度試行事業が 2009 年度より本格的に稼動 しているが, 小売業各社はメーカー各社とともに当初よ り参画し，制度設計において意見表明し PCR（Product
Category Rule) 策定および販売に取り組んでいる。同 制度は商品開発の原材料調達から製造, 輸送, 販売, 使 用, そして廃棄・リサイクルのライフサイクル全体での GHG（Green House Gas）を管理，削減するものである。 当然, 包装というライフサイクル段階も対象となる。 2008 年 12 月のエコプロダクツ展に 30 社の小売業, メーカーがカーボンフットプリントの統一マークを表示 した試作品を展示し話題となったが, 本当に社会から受 け入れられるかどうかは, 消費者 (生活者) が理解して くれるかどうか，また多くの企業（プレイヤー）が参画

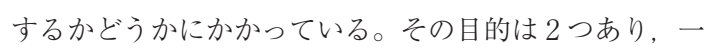
つは「開発する企業が当該商品のライフサイクルから出 る GHG を削減することを社会に約束する」ことであり， 他の一つは「LCA（Life Cycle Assessment）の活用によ り, GHGの排出とコストをより顕在化させ, 共に削減す る」ことにある。それにはサプライチェーン全体のマネ ジメントが必須となる。容器包装プラスチックの 3R 推 進においても, 今後さらに必要となる領域である。

\section{4. 小売業界からみた, 現在の容器包装リサイ クル法の課題}

\section{1 環境配慮設計（DfE：Design for Environment） の取り組み}

4.1 .1 容器包装プラスチックの薄肉化・軽量化

日本チェーンストア協会では，前述のとおり，1972 年より「包装適正化要綱」を策定し, 包装の三大機能 (商品の保護機能等) とのバランスに配慮しながら薄肉 化・軽量化に取り組んでおり，かなり進んできていると 思われる（レジ袋・トレイ含む）。現在は，お中元やお 歳暮商材といったギフト商品でも簡易包装化が進んでい る。これは, 環境問題に対する, 消費者 (生活者) の意 識の変化が底流にあると思われる。それは前述の減装 ショッピングの社会実験からも推察できるところである が, 今後の課題はそのシステム化をいかに成し遂げるか であろうと思う。

4.1 .2 素材変更に向けたインセンティブ設計

DfEの取り組みには削減とともに素材変更がある。 具体的には再生プラスチックやバイオマスプラスチック の導入等があげられる。それは容器包装プラスチックと ともに製品プラスチックにもあてはまる。2010 年 3 月 16 日の中央環境審議会と産業構造審議会の合同会合 (容器包装リサイクル WG プラスチック製容器包装に係 る再商品化手法検討会）にプラスチックマテリアルリサ イクル最終製品利用推進協議会が発表した「材料リサイ クル製品の用途（2008 年 4 月〜2009 年 6 月までの販売 
実績)」によると,「日用雑貨品・その他」は $2.9 \%$ となっ ており，いかに少ないかを示している8)。日用雑貨品の プラスチックは容器包装ではなく製品プラスチックであ るが, 容器包装と同様, 消費者 (生活者) が頻度多く日 常目にするものであり, 容器包装プラスチックと同様に 素材変更 (再生プラスチックおよびバイオマスプラス チック導入）の比率を上げていき, 消費者のグリーン購 入への行動変容をうながしていくべき対象である。その ためには，それに積極的に取り組む企業や自治体等に何 らかのインセンティブを与える制度設計が必要と考える。

\section{2 特定事業者の義務履行状況の公開}

容器包装リサイクル法は申告主義であり「ただ乗り事 業者」や「過少申告事業者」と推察される問題が完全に 解決されていない。前者については, 容器包装リサイク ル法第 20 条に基づくただ乗り事業者の公表が, 複数回 実施されているが, 義務履行違反に対する十分な抑制力 が働いているとはいいがたい状況にまだある。後者の問 題と合わせた対策はやはり適切な情報の公開により社会 のモニタリングの機能を強化すべきである。政府の地方 組織等を動員して指導すべきであるという意見もあるよ うだが，それには多額の税金を使うことになり非現実的 である。

\section{3 市町村の分別収集・選別保管コストの公開と効率 性を評価するモノサシの導入}

市町村による分別収集・選別保管コストについては, 2005 年, 環境省による調査があり, 直営・委託といっ た事業形態よりも市町村間の単価の違いの方が大きいこ とが報告されている。企業経営では管理会計があり，常 に効率性等がチェックされ，ベストプラクティスをベン チマークする組織運営がなされている。市町村の廃棄物 処理においてもコスト計算の標準化や事業効率・費用便 益の評価制度の確立に向けて制度設計すべき時がきてい ると思われる。

\section{4 特定事業者間の責任分担の公平性向上}

容器包装リサイクル法（プラスチック製容器）におけ る特定事業者の責任分担については，利用事業者と製 造事業者の負担割合に不公平感がある。2010 年度でみ ると利用事業者対製造事業者の按分比率は $96.19 \%$ vs $0.81 \%$ となっている。これは現在の法では「容器利用食 料品製造業種と食料品製造業種に容器を出荷する製造業 種の販売額の比率」で按分されるようになっているから である。すなわち 1 枚数円のレジ袋やトレイに対しレジ 袋に購入しようとする食料品を入れた総額やトレイにス
テーキなどの食料品をのせた総額（販売額）との比率で 再商品化義務量が算出されており不合理であり, 不公平 感がある。川上から川下まで部門ごとの事業者によるバ ランスのとれた, 公平性を向上させた責任分担の在り方 を検討すべきである。

\section{5.おわりに}

本稿では, 小売業の視点から見た容器包装プラスチッ

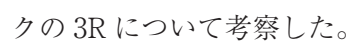

消費者に最も近い産業としての小売業からみると, 消 費者, 地域行政そして小売業などの事業者との連携によ る「消費者への環境配慮商品の選択への誘導」策の展開 が最もむずかしいが, しかし一番必要であることがわ かった。そのために, 今後検討すべき課題として次の 2 点がある。

一つは, OECD の EPR ガイドラインマニュアルが分 析した「容器包装は, 自動車や家電と違って, ブランド 別の回収・再商品化を行うことは非現実的なので集合的 に扱わざるを得ない。その結果，個々の企業の負担金は， その使用する容器包装の重量や個数に基づいて算出され ることになり，環境配慮設計（DfE）努力が反映されず, EPR が軽量化や減量には効果があったものの, DfEの 促進には効果が限定的であった」との指摘をどうとらえ るのか, という課題である。

この点に関して, 私は 2010 年 7 月上旬, 日本チェー ンストア協会主催の容器包装リサイクル欧州調査に参加 し, イギリスの WRAP (Waste Resouce Action Plan) 本部を訪問, 容器包装の DfEの成功事例をいくつか学 び, 現在分析を行っているところである。また, WRAP では, 「更なる容器包装のデザイン変更等の DfE を促進 する」ためのより明確なガイダンス（指針）を検討中で あり，完成すればわれわれにも情報提供してくれるので， 今後も, DfE（容器包装を含む）の在り方をさらに検討 し, 実現の可能性を追求していきたいと考えている。い ずれにしても事業者にDfEに対する適正なインセン ティブが作用し, 環境配慮商品（容器包装含む）が市場 に多く登場すれば，消費者の選択の幅は拡大していく。

他の一つは, 生態系をモデルとした産業活動である 「産業エコロジー」の概念を容器包装の分野にも導入で きないかという課題である。ある産業の廃棄物を別の産 業が資源として利用する, この概念は今後の循環型社会, 低炭素社会の構築にとって重要な考え方ではないかと思 われる。産学官民共同体（サステナビリティコンソー シャム）のような推進組織で真剣に検討すべき時ではな いだろうか。 
参 考文 献

1） $\mathrm{PET}$ ボトルリサイクル推進協議会：ヨーロッパの容器 包装リサイクル制度——拡大生産者責任（EPR）に対 する評価——(2010)

2) 財食品産業センター: 複合素材のプラスチック製容器 包装と食品, ヒアリング資料 9

http : //www.meti.go.jp/committee/materials2/ downloadfiles/g100330d11j.pdf (2010)

3) 日本チェーンストア協会：チェーンストアと容器包装 リサイクル，その対応と課題（2010）

4）日本チェーンストア協会：包装適正化要綱（1972）

5 ）日本チェーンストア協会 : 容器包装リサイクル法の見 直しについて http : //www. env.go.jp/council/03haiki/y30-kondan06/ mat05.pdf (2010)

6) 日本チェーンストア協会：チェーンストアにおける容 器包装の $3 \mathrm{R}$ の取り組み——その現状と課題—— http ://www.meti.go.jp/committee/materials2/ downloadfiles/g100330d09j.pdf (2010)

7 ) 石川雅紀 : $\mathrm{CO}_{2}$ 削減に向けた包装ごみの発生抑制, 食 品と科学, 第 52 巻, 第 5 号, pp. 73-77 (2010)

8) プラスチックマテリアルリサイクル最終製品利用推進 協議会 : 材料リサイクル製品の用途, 中央環境審議会, 産業構造審議会合同会合, プラスチック製容器包装に 係る再商品化手法作業チーム発表資料（2010）

\title{
Retail Industry Views on 3Rs for Plastic Containers and Packaging
}

\author{
Seiichi Ueyama \\ Environmental Management Institute for Retail Industry \\ (Former Managing Director Corporate Citizenship, AEON RETAIL Co., Ltd.) \\ (2-5-23-101 Yatsu, Ageo, Saitama 362-0042 Japan)
}

\begin{abstract}
There are many issues that remain unresolved and continue to be the topic of discussion where the recycling of plastics is concerned, especially in relation to targets set out in The Containers and Packaging Recycling Law.

The retail industry has positioned itself to be the closest link to consumers. This article investigates the current activities, latest updates, and possible future directions of the retail industry. Containers and various forms of packaging have three major functions : content protection, provision of marketing information and convenience of handling. Environmental friendliness must be taken into account (i. e., single materialization) when emphasizing the importance of any of these functions. Finding a balance between function and environmental friendliness is one of the forefronts in the discussion on packaging.

At the same time, policies for reducing use now hold even greater importance. The retail industry has been working on a wide variety of measures over the past 40 years, including cooperating with local consumers and governments and pursuing the concept of sustainability. The issues surrounding The Containers and Packaging Recycling Law all aim to ensure the ideas of transparency and fairness. Additionally, there is a need for more inventive design concepts that give an incentive to business entities looking toward distribution of recycled plastics and plant-based plastics, such as biomass materials. In particular, there is a need for greater discussion on institutional design for Policy Guidance on the Selection of Environmentally-Friendly Products.
\end{abstract}

Keywords : DfE (Design for Environment), cooperation, reduce, green purchasing, transparency and fairness 